\title{
Klasifikasi Jenis dan Tingkat Kesegaran Daging Berdasarkan Warna, Tekstur dan Invariant Moment Menggunakan Klasifikasi LDA
}

\author{
(Classification of Type and Freshness Level of Meat Based on Color, Texture and \\ Invariant Moment Using LDA Classification)
}

\author{
Siti Faria Astari, I Gede Pasek Suta Wijaya*, Ida Bagus Ketut Widiartha \\ Dept Informatics Engineering, Mataram University \\ Jl. Majapahit 62, Mataram, Lombok NTB, INDONESIA \\ Email: sitifaria21@gmail.com, gpsutawijaya@unram.ac.id,widi@unram.ac.id
}

\section{*Penulis Korespondensi}

\begin{abstract}
Distribution process that takes a long time along with improper treatment, can cause meat become not fresh and decrease the quality of the meat. Therefore, unscrupulous meat sellers cheating on the non-fresh meat by mixing the non-fresh meat with the fresh one. A system that can classify the type and freshness level of meat automatically is needed. In this research, that system was developed based on texture, color and shape features using Linear Discriminant Analysis (LDA) classification. The methods used in the feature extraction process are statistical approach, GLCM and the HU's invariant moment. The total of data used in this research was 960 images of 3 different meat types which are chicken meat, goat meat, and beef. The highest accuracy obtained from the testing process was $90 \%$ on the combination features of HSI and invariant moment for the meat type in refrigerator.
\end{abstract}

Key words: Meat type and freshness level, statistics, GLCM, Invariant Moment, LDA.

\section{PENDAHULUAN}

Daging merupakan makanan utama yang dikonsumsi oleh manusia. Berdasarkan data statistik, konsumsi daging meningkat 5.69 persen dari konsumsi tahun 2015 sebesar $6,413 \mathrm{~kg}$. Konsumsi daging ayam ras per kapita tahun 2016 sebesar $5,110 \mathrm{~kg}$, mengalami peningkatan sebesar 6.52 persen dari tahun 2015 sebesar $4.797 \mathrm{~kg}$ [1].

Proses distribusi daging, dimulai dari tempat pemotongan sampai ke tangan konsumen memakan waktu yang cukup lama ditambah dengan perlakuan yang kurang tepat, dapat menyebabkan daging menjadi tidak segar dan menurunnya kualitas dari daging tersebut. oleh karena itu, oknum pedagang daging melakukan kecurangan untuk mengakali daging yang tidak segar tersebut, dengan cara mencampurkan daging tidak segar dengan daging segar. Para konsumen awam tidak menyadari tindakan pencampuran daging-daging tersebut, karena secara kasat mata sulit dibedakan.
Jenis daging dapat dibedakan berdasarkan fitur tekstur dan warna menggunakan berbagai macam metode klasifikasi, salah satunya menggunakan metode $k$ Nearest Neighbor (KNN) [2] dan Support Vector Machine (SVM) [3]. Selain fitur tekstur dan warna, fitur lain yang dapat diekstraksi adalah fitur invariant moment [4].

Salah satu metode yang dapat digunakan untuk melakukan klasifikasi dalam pengenalan pola yakni metode Linear Discriminant Analysis (LDA). Metode LDA memiliki beberapa keunggulan dibandingkan metode yang lain seperti relatif mudah diimplementasikan karena hanya memiliki co-occurrent dan nilai rata-rata global $(\mu)$ dari Eigen Analysis, model klasifikasi yang relatif dan telah banyak mengimplementasikan LDA classifier dengan hasil yang baik dengan waktu komputasi yang pendek. Sehingga metode ini dapat digunakan dalam sistem pengenalan pola klasifikasi jenis dan tingkat kesegaran daging.

Berdasarkan hal tersebut, maka dalam penelitian ini akan dibangun suatu sistem klasifikasi jenis daging beserta tingkat kesegarannya guna menambahkan fitur pada hasil dari penelitian yang telah dilakukan sebelumnya [3]. Sistem yang dibangun dapat membedakan jenis daging seperti daging sapi, ayam atau kambing serta dapat mengetahui tingkat kesegarannya dengan pendekatan pengolahan citra digital. Metode ekstraksi fitur yang digunakan antara lain metode Statistik untuk ekstraksi fitur warma, Gray-Level Co-occurrence Matrix (GLCM) untuk proses ekstraksi fitur tekstur, dan metode Hu's Invariant Moment untuk fitur moment, dimana hasil ekstraksi tersebut akan diklasifikasi menggunakan Linear Discriminant Analysis (LDA).

\section{TINJAUAN PUSTAKA}

Beberapa penelitian yang terkait dengan klasifikasi jenis daging telah dilakukan sebelumnya oleh beberapa peneliti. Penelitian-penelitian tersebut menggunakan beberapa metode ekstraksi fitur maupun metode klasifikasi yang beragam. Pada penelitian yang menggunakan metode GLCM untuk melakukan klasifikasi jenis daging 
berdasarkan fitur tekstur telah berhasil dilakukan dengan tingkat akurasi yang diperoleh $73.3 \%$ [5]. Selain itu, metode GLCM juga digunakan untuk melakukan klasifikasi jenis daging berdasarkan analisis citra tekstur dan warna dengan tingkat akurasi 75.6\% [6].

Pada penelitian pengolahan citra dengan ekstraksi fitur menggunakan histogram model warna untuk fitur warna dan metode orde 2 untuk ekstraksi fitur tekstur telah berhasil dilakukan. Dimana tingkat akurasi tertinggi yang diperoleh mencapai $88.75 \%$ untuk citra tanpa background dan $73.375 \%$ untuk citra dengan background [7].

Pada penelitian dengan fitur tekstur dan warna juga dianalisis untuk mengetahui jenis dan kualitas daging konsumsi. Pada penelitian ini, diperoleh hasil dengan tingkat akurasi sebesar kurang lebih $86.5455 \%$ dengan waktu komputasi kurang lebih 240.4143 detik [2].

Selanjutnya untuk ekstraksi fitur invariant moment, telah dilakukan pada penelitian untuk mendeteksi obyek yang telah mengalami transformasi. Penelitian ini menunjukkan bahwa dari moment citra asli dan moment citra yang telah diubah memiliki perubahan yang relatif kecil, sehingga dapat disimpulkan bahwa invariant moment dapat digunakan untuk pengenalan obyek yang telah mengalami proses transformasi [8]. Selain itu pada penelitian pengenalan pola pada citra digital yang menggunakan fitur invariant moment, diperoleh tingkat akurasi mencapai $100 \%$ dari 8 objek berbeda [4]

Selain klasifikasi jenis daging, terdapat penelitian yang melakukan klasifikasi tingkat kesegaran daging. Klasifikasi tingkat kesegaran daging sapi menggunakan metode GLCM dan klasifikasi SVM (Support Vector Machine). Tingkat akurasi tertinggi yang diperoleh dalam penelitian ini mencapai $97 \%$ pada ruang warna HSI [3].

Beragam metode klasifikasi pun dapat digunakan dalam mengklasifikasi tingkat kesegaran daging. Klasifikasi menggunakan metode PNN Neural Network bertujuan untuk mengembangkan sistem on-line pengidentifikasi tingkat kesegaran daging babi, dimana diperoleh tingkat akurasi sebesar $88 \%$ [9].

Metode lain yang dapat digunakan dalam pengenalan pola adalah LDA (Linear Discriminant Analysis). Dalam penelitian ini, dibuat suatu sistem pengenalan wajah menggunakan 2 metode, salah satunya metode LDA. Tingkat akurasi yang diperoleh dari penelitian berkisar antara $80-90 \%$ dengan berbagai variasi penambahan noise dan oklusi [10]. Penelitian mengenai pengenalan wajah dengan metode LDA juga telah berhasil dilakukan, dimana tingkat akurasi yang diperoleh sampai $98.33 \%$ dari 66 citra wajah dari 22 orang [11].

Pada penelitian yang berjudul Pengenalan Ekspresi Wajah Menggunakan DCT Dan LDA Untuk Aplikasi Pemutar Musik (MOODSIC), secara real-time aplikasi ini memberikan hasil yang cukup baik dengan akurasi pengenalan ekspresi sebesar $91.51 \%$ atau dengan tingkat kesalahan pengenalan $9.49 \%$ [12].

Oleh karena itu, berdasarkan pemaparan di atas, maka dalam penelitian ini akan dibuat suatu sistem yang dapat melakukan klasifikasi jenis dan tingkat kesegaran daging.
Metode yang digunakan untuk ekstraksi fitur warna dan tekstur adalah metode GLCM, yang pada penelitianpenelitian sebelumnya memperoleh tingkat akurasi tertinggi hingga 97\%. Sedangkan klasifikasi yang digunakan adalah LDA yang mampu memperoleh tingkat akurasi tertinggi hingga $98.33 \%$.

\section{Metode Penelitian}

\section{A. Pendekatan penelitian}

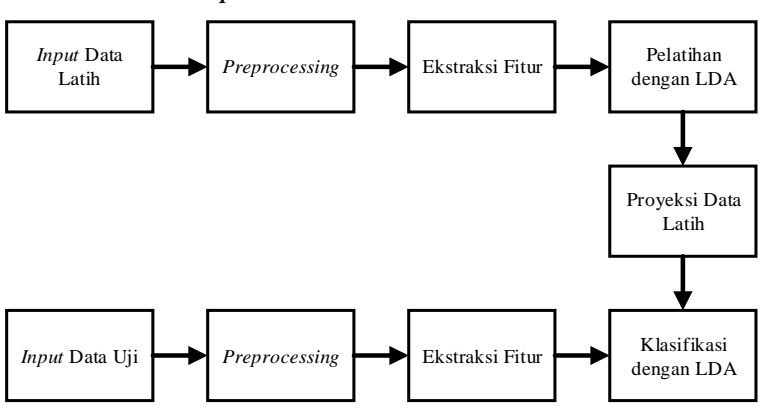

Gambar 1. Pendekatan penelitian

Gambar 1 menunjukkan tahapan dalam penelitian, tahap pertama yakni citra yang telah di-crop dan di-resize secara manual di luar sistem dimasukkan untuk dilatih. Selanjutnya tahap preprocessing, pada tahap ini gambar akan dikonversi ruang warnanya dari RGB ke grayscale dan HSI. Gambar HSI digunakan untuk ekstraksi fitur warna sedangkan gambar grayscale digunakan untuk ekstraksi fitur tekstur dan invariant moment. Adapun pada tahap ekstraksi fitur, metode statistik digunakan untuk ekstraksi fitur warna, metode GLCM digunakan untuk fitur tekstur dan metode $\mathrm{HU}$ digunakan untuk fitur invariant moment. Fitur-fitur tersebut kemudian dilatih menggunakan LDA. Hasil pelatihannya berupa proyeksi data yang disimpan dan digunakan dalam proses klasifikasi.

\section{B. Pengambilan data}

Proses pengumpulan data untuk daging sapi, ayam dan kambing dilakukan dengan dua cara yakni pada lemari es dan suhu ruang. Pada suhu ruangan, proses pembusukan daging sapi mulai terjadi pada jam ke-9, sedangkan untuk daging sapi yang disimpan dalam lemari es, proses pembusukan mulai terjadi pada jam ke-18 [13]. Daging kambing yang merupakan daging merah mengalami proses pembusukan yang hampir sama dengan daging sapi. Sedangkan untuk daging ayam, pada suhu ruang proses pembusukan akan mulai terjadi pada jam ke-6, dan untuk daging ayam yang disimpan pada lemari es proses pembusukan mulai terjadi sejak jam ke-12 [14]. Pengambilan citra dilakukan dengan jarak pengambilan sejauh $20 \mathrm{~cm}$ dengan rincian waktu pengumpulan data dapat dilihat pada Tabel I. 
TABEL I. WAKtu Pengumpulan Data Daging

\begin{tabular}{|c|c|c|c|c|c|c|}
\hline \multirow{2}{*}{ Dataset } & \multicolumn{2}{|c|}{ Ayam } & \multicolumn{2}{c|}{ Kambing } & \multicolumn{2}{c|}{ Sapi } \\
\cline { 2 - 7 } & LE & SR & LE & SR & LE & SR \\
\hline $\begin{array}{c}\text { Interval waktu pengambilan } \\
\text { (jam) }\end{array}$ & 2 & 1 & 2 & 2 & 5 & 2 \\
\hline $\begin{array}{c}\text { Lama waktu pengambilan } \\
\text { (jam) }\end{array}$ & 24 & 20 & 36 & 26 & 55 & 27 \\
\hline
\end{tabular}

Masing-masing dataset daging terdiri atas 320 citra, sehingga total citra yang digunakan yaitu sebanyak 960 citra. Rincian distribusi dataset dapat dilihat pada Tabel II. Contoh citra daging ayam, kambing dan sapi masingmasing dapat dilihat pada Tabel III, Tabel IV dan Tabel V.

TABEL II. RINCIAN DISTRIBUSI DATASET

\begin{tabular}{|c|c|c|c|}
\hline \multirow{4}{*}{$\begin{array}{c}\text { Daging } \\
\text { ayam }\end{array}$} & \multirow{2}{*}{ Lemari es } & Segar & 160 \\
\hline & & Tidak Segar & 160 \\
\hline & \multirow{2}{*}{ Suhu ruang } & Segar & 160 \\
\hline & & Tidak Segar & 160 \\
\hline \multirow{4}{*}{$\begin{array}{l}\text { Daging } \\
\text { kambing }\end{array}$} & \multirow{2}{*}{ Lemari es } & Segar & 160 \\
\hline & & Tidak Segar & 160 \\
\hline & \multirow[b]{2}{*}{ Suhu ruang } & Segar & 160 \\
\hline & & Tidak Segar & 160 \\
\hline \multirow{4}{*}{$\begin{array}{c}\text { Daging } \\
\text { Sapi }\end{array}$} & \multirow{2}{*}{ Lemari es } & Segar & 160 \\
\hline & & Tidak Segar & 160 \\
\hline & \multirow{2}{*}{ Suhu ruang } & Segar & 160 \\
\hline & & Tidak Segar & 160 \\
\hline
\end{tabular}

TABEL III. CONTOH Citra DAGING AYAM

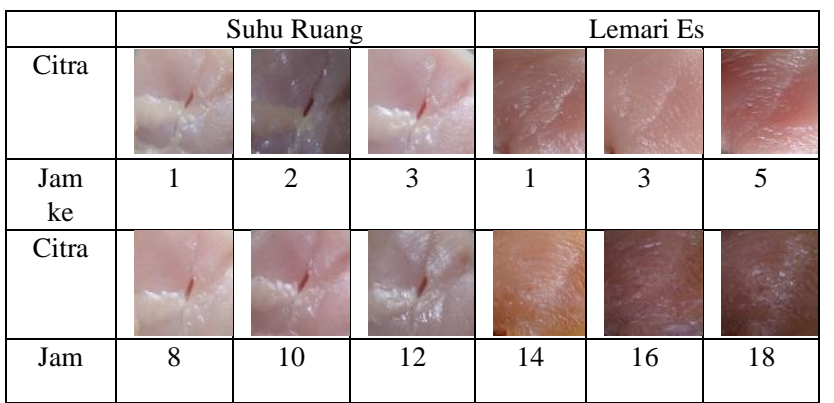

TABEL IV. CONTOH Citra Daging Kambing

\begin{tabular}{|c|c|c|c|c|c|c|}
\hline & \multicolumn{3}{|c|}{ Suhu Ruang } & \multicolumn{3}{c|}{ Lemari Es } \\
\hline Citra & & & & & & \\
\hline $\begin{array}{c}\text { Jam } \\
\text { ke- }\end{array}$ & 1 & 3 & 5 & 1 & 5 & 7 \\
\hline $\begin{array}{c}\text { Citra } \\
\text { Jam } \\
\text { ke- }\end{array}$ & 13 & 17 & 21 & 23 & 27 & 29 \\
\hline
\end{tabular}

TABEL V. CONTOH Citra Daging SAPI

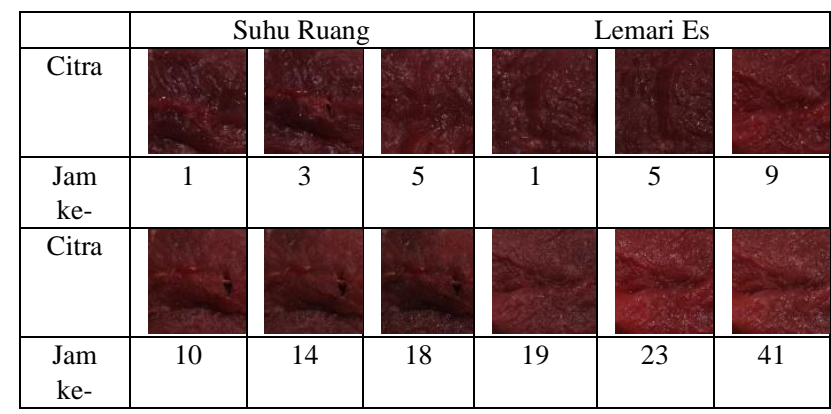

C. Preprocessing

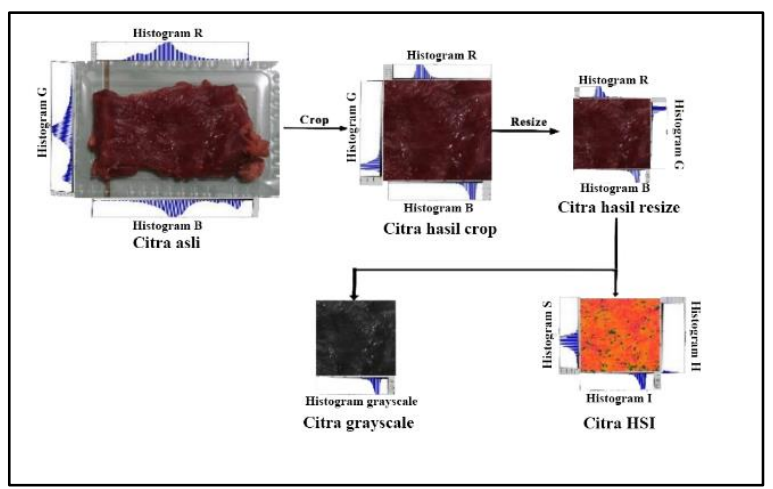

Gambar 2. Tahap preprocessing

Pada tahap ini gambar akan dikonversi ruang warnanya. Konversi ruang warna dilakukan dari RGB ke ruang warna HSI dan dari RGB ke ruang warna grayscale. Pada ruang warna HSI, Hue berasosiasi dengan panjang gelombang cahaya, Saturation menyatakan tingkat kemurnian suatu warna, dan Intensity adalah atribut yang menyatakan banyaknya cahaya yang diterima oleh mata tanpa memperdulikan warna. Rumus konversi ruang warna RGB ke HSI dapat dilihat pada Persamaan (1) sampai (4).

$$
\mathrm{H}=\left\{\begin{array}{r}
\theta \text { jika } B \leq G \\
360-\theta \text { jika } B>G
\end{array}\right.
$$

Dengan

$$
\begin{gathered}
\theta=\cos ^{-1}\left\{\frac{\frac{1}{2}[(R-G)+(R-B)]}{\left[(R-G)^{2}+(R-B)(G-B)\right]^{\frac{1}{2}}}\right\} \\
S=1-\frac{3}{(R+G+B)}[\min (R, G, B)] \\
I=\frac{R+G+B}{3}
\end{gathered}
$$

Gambar dalam ruang warna grayscale digunakan untuk ekstraksi fitur tekstur dan ekstraksi fitur invariant moment. Gambar 3 menunjukkan contoh hasil konversi ruang warna RGB ke HSI, grayscale, dan $\mathrm{YCbCr}$ pada suatu citra daging sapi. 


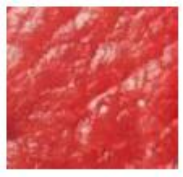

(a)

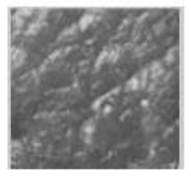

(b)

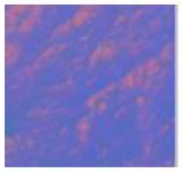

(c)

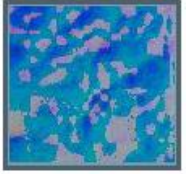

(d)
Gambar 3. Hasil konversi ruang warna (a) RGB. (b) Grayscale. (c) YcbCr. (d) HSI

\section{Ekstraksi fitur}

Proses ekstraksi fitur ini dilakukan untuk mendapatkan fitur warna, tekstur dan invariant moment. Fitur warna diekstraksi menggunakan metode statistik, fitur tekstur diekstraksi menggunakan metode GLCM dan fitur invariant moment diekstraksi menggunakan metode HU.

\section{D.1 Ekstraksi fitur warna dengan metode Statistik}

Langkah awal ekstraksi fitur warna dengan metode statistik yakni menghitung nilai mean, median, modus dan variance dari satu gambar dalam ruang warna HSI. Setiap fitur statistik akan diekstraksi berdasarkan format HSI [15] 1. Mean

Mean merupakan nilai rata-rata dari semua angka. Mean dapat dihitung dengan menggunakan Persamaan (5).

$$
\mathrm{X}_{\mathrm{n}}=\frac{x 1+x 2+x 3+\cdots+x n}{n}
$$

\section{Median}

Median adalah nilai tengah atau titik tengah dalam suatu nomor urut. Jika nilai ganjil maka median dapat langsung ditemukan, tetapi jika nilai genap, maka median dihitung sebagai rata-rata dari dua angka tengah.

\section{Modus}

Modus merupakan angka yang paling sering muncul dalam suatu himpunan angka.

\section{Variance}

Jika mempunyai sampel berukuran $\mathrm{n}$ dengan data $\mathrm{x}_{1}$, $\mathrm{x}_{2}, \ldots \mathrm{x}_{\mathrm{n}}$ dan rata-rata $\mathrm{x}$, maka variance dapat dihitung dengan Persamaan (6).

$$
S^{2}=\frac{\sum\left(x i-x^{\prime}\right)^{2}}{n-1}
$$

\section{D.2 Ekstraksi fitur tekstur dengan metode GLCM}

Gray level Co-Ocurance Matrix (GLCM) merupakan salah satu metode yang digunakan untuk analisis fitur tekstur. Ada 14 fitur tekstur yang dapat diekstraksi dengan menggunakan metode ini, tetapi pada penelitian ini hanya digunakan 5 fitur dari 14 fitur tekstur tersebut. Tahap pertama pada metode GLCM adalah membuat matriks GLCM. Matriks GLCM harus dibuat berdasarkan empat arah yakni $0^{\circ}, 45^{\circ}, 90^{\circ}$ dan $135^{\circ}$ seperti pada Gambar 4 .

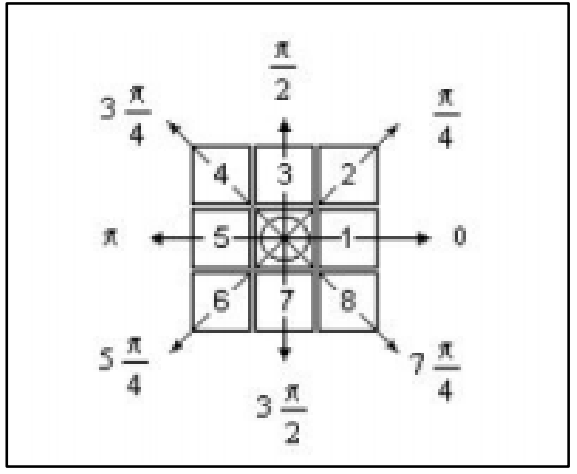

Gambar 4. Piksel bertetangga dalam delapan arah [16]

Selanjutnya, menghitung nilai ke-5 fitur tersebut dengan cara sebagai berikut [16]:

1. Energi (Energy)

2. Entropi (Entropy)

$$
\mathrm{f}_{1}=\Sigma_{\mathrm{i}} \Sigma_{\mathrm{j}}\{\operatorname{Pd}(\mathrm{i}, \mathrm{j})\}^{2}
$$

$$
\mathrm{f}_{2}=-\Sigma_{\mathrm{i}} \Sigma_{\mathrm{j}} \operatorname{Pd}(\mathrm{i}, \mathrm{j}) \log (\operatorname{Pd}(\mathrm{i}, \mathrm{j}))
$$

3. Kontras (Contrast)

$$
\mathrm{f}_{3}=\Sigma_{\mathrm{i}} \Sigma_{\mathrm{j}}(\mathrm{i}-\mathrm{j})^{2} \operatorname{Pd}(\mathrm{i}, \mathrm{j})
$$

4. Homogenitas (Homogeneity)

$$
\mathrm{f}_{4}=\Sigma_{\mathrm{i}} \Sigma_{\mathrm{j}} \frac{\operatorname{Pd}(\mathrm{i}, \mathrm{j})}{1+|\mathrm{i}-\mathrm{j}|}
$$

\section{Korelasi (Correlation)}

$$
\mathrm{f}_{5}=\Sigma_{\mathrm{i}} \Sigma_{\mathrm{j}} \frac{\mathrm{ijPd}(\mathrm{i}, \mathrm{j})-\mu \mathrm{x} \mu \mathrm{y}}{\sigma \mathrm{x} \sigma \mathrm{y}}
$$

\section{D.3 Ekstraksi fitur invariant moment dengan metode $\mathrm{Hu}$}

Proses ini bertujuan untuk mencari 7 fitur invariant moment dari suatu citra. Momen dapat menggambarkan suatu objek dalam hal area, posisi, orientasi dan parameter terdefinisi lainnya. Persamaan dasar dari momen suatu objek didefinisikan sebagai berikut:

$$
m_{i j}=\sum_{x} \sum_{y} x^{i} y^{j} a_{x y}
$$

Pusat dari area atau massa (centroid) adalah parameter yang baik untuk menyatakan lokasi dari objek. Pusat area dari objek didefinisikan pada Persamaan (13), momen pusat objek didefinisikan pada Persamaan (14), dan momen pusat yang ternormalisasi didefinisikan pada Persamaan (15).

$$
\begin{gathered}
x^{\prime}=\frac{m_{10}}{m_{00}} \text { dan } y^{\prime}=\frac{m_{10}}{m_{00}} \\
\mu_{i j}=\sum_{x} \sum_{y}\left(x-x^{\prime}\right)^{i}\left(y-y^{\prime}\right)^{j} a_{x y}
\end{gathered}
$$




$$
\eta_{i j}=\frac{\mu_{i j}}{\left(\mu_{00}\right)^{\lambda}}
$$

Dengan $\lambda=\frac{(i+j)}{2}+1$

Dari moment pusat yang telah ternormalisasi, maka 7 invariant moment dapat ditentukan. Persamaan (16) sampai (22) merupakan rumus untuk mencari invariant moment ke-1 sampai 7.

$$
\begin{aligned}
\phi_{1}= & \eta_{20}+\eta_{02} \\
\phi_{2}= & \left(\eta_{20}+\eta_{02}\right)^{2}+4 \eta_{11}^{2} \\
\phi_{3}= & \left(\eta_{30}-3 \eta_{12}\right)^{2}+\left(3 \eta_{21}-\eta_{03}\right)^{2} \\
\phi_{4}= & \left(\eta_{30}+\eta_{12}\right)^{2}+\left(\eta_{21}-\eta_{03}\right)^{2} \\
\phi_{5}= & \left(\eta_{30}-3 \eta_{12}\right)\left(\eta_{30}+\eta_{12}\right)\left\{\left(\eta_{30}+\eta_{12}\right)^{2}-\right. \\
& \left.3\left(\eta_{21}+\eta_{03}\right)^{2}\right\}+\left(3 \eta_{21}-\eta_{03}\right)\left(\eta_{21}+\right. \\
& \left.\eta_{03}\right)\left\{3\left(\eta_{30}+\eta_{12}\right)^{2}-\left(\eta_{21}+\eta_{03}\right)^{2}\right\} \\
\phi_{6}= & \left(\eta_{20}-\eta_{02}\right)\left\{\left(\eta_{30}+\eta_{12}\right)^{2}-\left(\eta_{21}+\right.\right. \\
& \left.\left.\eta_{03}\right)^{2}\right\}+4 \eta_{11}\left(\eta_{30}+\eta_{12}\right)\left(\eta_{21}+\eta_{03}\right) \\
\phi_{7}= & \left(3 \eta_{21}-\eta_{30}\right)\left(\eta_{30}+\eta_{12}\right)\left\{\left(\eta_{30}+\eta_{12}\right)^{2}-\right. \\
& \left.3\left(\eta_{21}+\eta_{03}\right)^{2}\right\}+\left(3 \eta_{21}-\eta_{03}\right)\left(\eta_{21}+\right. \\
& \left.\eta_{03}\right)\left\{3\left(\eta_{30}+\eta_{12}\right)^{2}-\left(\eta_{21}+\eta_{03}\right)^{2}\right\}
\end{aligned}
$$

\section{D.4 Klasifikasi dengan LDA}

Sistem klasifikasi jenis dan tingkat kesegaran daging ini menggunakan klasifikasi LDA. Metode klasifikasi LDA digunakan untuk mendapatkan sebaran data yang tingkat diskriminannya optimal. Untuk memperoleh proyeksi data yang akan digunakan untuk klasifikasi, dicari matriks scatter within class $\left(\mathrm{S}_{\mathrm{W}}\right)$ dan matriks scatter between class $\left(\mathrm{S}_{\mathrm{B}}\right)$.

$$
\begin{gathered}
S_{W}=\sum_{\mathrm{i}=1}^{\mathrm{c}} \sum_{\mathrm{x}_{\mathrm{k}} \in \mathrm{x}_{\mathrm{i}}}\left(\mathrm{x}_{\mathrm{k}}-\mu_{\mathrm{i}}\right)\left(\mathrm{x}_{\mathrm{k}}-\mu_{\mathrm{i}}\right)^{\mathrm{T}} \\
S_{B}=\sum_{\mathrm{i}=1}^{\mathrm{c}} N_{i}\left(\mathrm{x}_{\mathrm{k}}-\mu_{\mathrm{i}}\right)\left(\mathrm{x}_{\mathrm{k}}-\mu_{\mathrm{i}}\right)^{\mathrm{T}}
\end{gathered}
$$

Dimana $N_{i}$ adalah jumlah sample pada kelas $\mathrm{X}_{\mathrm{i}}$, dan $\mu_{\mathrm{i}}$ adalah image rata-rata dari kelas $\mathrm{X}_{\mathrm{i}}$. Selanjutnya mencari eigen vector untuk digunakan dalam proyeksi data berdasarkan eigen value terbesar.

$$
\mathrm{S}_{B} \Psi=S_{W} \Psi \Lambda
$$

Dimana $\Psi$ merupakan matriks eigen vector dan $\Lambda$ merupakan eigen value.

\section{HASIl DAN PEMBAHASAN}

Pengujian dilakukan beberapa kali untuk dapat mengetahui pengaruh dari beberapa parameter terhadap hasil klasifikasi. Adapun parameter-parameter yang digunakan dalam penelitian ini seperti pengaruh resolusi citra terhadap akurasi dan pengaruh rotasi terhadap akurasi.

\section{A. Pengaruh resolusi citra terhadap akurasi}

Pengujian pertama dilakukan untuk menguji pengaruh resolusi citra terhadap akurasi. Pengujian ini bertujuan untuk mencari resolusi citra yang lebih baik digunakan dalam mengklasifikasikan jenis dan tingkat kesegaran

\begin{tabular}{|c|c|c|c|c|c|c|c|c|}
\hline \multirow[b]{2}{*}{$\begin{array}{c}\text { Reso } \\
\text { lusi }\end{array}$} & \multirow[b]{2}{*}{$\begin{array}{c}\text { Data } \\
\text { set }\end{array}$} & \multicolumn{7}{|c|}{ Akurasi (\%) } \\
\hline & & $\mathbf{H}$ & G & $\mathbf{M}$ & $\underset{\text { G }}{\text { H+ }}$ & $\begin{array}{r}\text { H+ } \\
\mathbf{M}\end{array}$ & $\begin{array}{c}\text { G+ } \\
\mathbf{M}\end{array}$ & $\begin{array}{c}\text { H+ } \\
\text { G+ } \\
\text { M }\end{array}$ \\
\hline \multirow{2}{*}{$\begin{array}{c}256 \\
x \\
256\end{array}$} & LE & 80 & $\begin{array}{l}41 . \\
67\end{array}$ & $\begin{array}{l}68 . \\
33\end{array}$ & $\begin{array}{c}42 . \\
5\end{array}$ & $\begin{array}{c}78 . \\
3\end{array}$ & $\begin{array}{c}43 . \\
3\end{array}$ & $\begin{array}{l}40 . \\
83\end{array}$ \\
\hline & SR & $\begin{array}{l}64 . \\
17\end{array}$ & 60 & $\begin{array}{r}66 . \\
67\end{array}$ & $\begin{array}{l}60 . \\
83\end{array}$ & 75 & $\begin{array}{l}58 . \\
33\end{array}$ & 60 \\
\hline \multicolumn{2}{|c|}{ Rata-rata } & $\begin{array}{l}72 . \\
09\end{array}$ & $\begin{array}{l}50 . \\
84\end{array}$ & $\begin{array}{c}67 . \\
50\end{array}$ & $\begin{array}{l}51 . \\
67\end{array}$ & $\begin{array}{l}76 . \\
65\end{array}$ & $\begin{array}{l}50 . \\
82\end{array}$ & $\begin{array}{l}50 . \\
42\end{array}$ \\
\hline \multirow{2}{*}{$\begin{array}{c}512 \\
\mathrm{X} \\
512\end{array}$} & LE & $\begin{array}{l}80 . \\
83\end{array}$ & $\begin{array}{l}45 . \\
83\end{array}$ & $\begin{array}{l}65 . \\
83\end{array}$ & 50 & 90 & 40 & $\begin{array}{l}50 . \\
83\end{array}$ \\
\hline & SR & $\begin{array}{l}65 . \\
83\end{array}$ & 55 & $\begin{array}{r}66 . \\
67 \\
\end{array}$ & $\begin{array}{l}54 . \\
167\end{array}$ & $\begin{array}{r}69 . \\
167\end{array}$ & $\begin{array}{l}55 . \\
83\end{array}$ & 55 \\
\hline \multicolumn{2}{|c|}{ Rata-rata } & $\begin{array}{l}73 . \\
33\end{array}$ & $\begin{array}{l}50 . \\
42\end{array}$ & $\begin{array}{l}66 . \\
25\end{array}$ & $\begin{array}{l}52 . \\
08\end{array}$ & $\begin{array}{l}79 . \\
58\end{array}$ & $\begin{array}{r}47 . \\
92\end{array}$ & $\begin{array}{l}52 . \\
92\end{array}$ \\
\hline
\end{tabular}
daging menggunakan fitur warna, tekstur dan invariant moment. Citra dengan resolusi $256 \times 256$ piksel dan $512 \times 512$ piksel digunakan baik pada proses pelatihan maupun proses pengujian, kemudian dilakukan perbandingan terhadap hasil klasifikasinya. Hasil akurasi klasifikasi berdasarkan resolusi citra dapat dilihat pada Tabel VI untuk klasifikasi jenis daging dan Tabel VII untuk klasifikasi tingkat kesegaran daging. Kemudian dipilih fitur terbaik yang menghasilkan rata-rata akurasi terbesar dari klasifikasi jenis daging dan klasifikasi tingkat kesegaran daging, untuk digunakan pada klasifikasi gabungan jenis dan tingkat kesegaran daging, yang hasilnya dapat dilihat pada Tabel VIII.

TABEL VI. PENGaruh Resolusi Terhadap Hasil KLASIFIKasi JENIS DAGING

Keterangan: LE $=$ Lemari es, $\mathrm{SR}=$ Suhu ruang, $\mathrm{H}=\mathrm{HSI}$ $\mathrm{G}=\mathrm{GLCM}, \mathrm{M}=$ Moment

Berdasarkan hasil pengujian klasifikasi jenis daging dan tingkat kesegaran daging yang telah dilakukan, dapat dilihat bahwa perubahan resolusi tidak memberikan perubahan tingkat akurasi yang signifikan. Peningkatan resolusi citra tidak selalu berdampak baik pada akurasi yang dihasilkan. Contohnya pada fitur HSI+Moment pada klasifikasi jenis daging, rata-rata akurasi yang diperoleh pada citra 256x256 piksel sebesar $76.65 \%$ dan pada citra $512 \times 512$ piksel sebesar $79.58 \%$, dengan peningkatan hanya sebesar $2.93 \%$. Sebaliknya, pada fitur GLCM+Moment terjadi penurunan rata-rata akurasi sebesar $2.9 \%$ dari penggunaan citra 256x256 piksel ke 512x512 piksel.

Selanjutnya dipilih fitur terbaik dari masing-masing klasifikasi untuk digunakan dalam klasifikasi gabungan jenis dan tingkat kesegaran daging. Pada jenis daging digunakan fitur HSI+Moment untuk kedua resolusi, sedangkan pada klasifikasi kesegaran digunakan fitur Moment untuk resolusi 256x256, dan fitur HSI dan HSI+Moment untuk resolusi 512x512. Hasil pengujiannya dapat dilihat pada Tabel VIII. 
TABEL VII. PENGARUH ReSOlusi TERHADAP HASIL KLASIFIKASI TingKat KeSEgaran DAging

\begin{tabular}{|c|c|c|c|c|c|c|c|c|c|}
\hline \multirow[b]{2}{*}{$\begin{array}{l}\text { Res } \\
\text { olusi }\end{array}$} & \multirow[b]{2}{*}{$\begin{array}{c}\text { Jenis } \\
\text { da- } \\
\text { ging }\end{array}$} & \multirow[b]{2}{*}{$\begin{array}{c}D a \\
\text { ta } \\
\text { set }\end{array}$} & \multicolumn{7}{|c|}{ Akurasi (\%) } \\
\hline & & & $\mathbf{H}$ & G & M & $\begin{array}{c}\text { H+ } \\
\text { G }\end{array}$ & $\begin{array}{c}\mathbf{H}+ \\
\mathbf{M}\end{array}$ & $\begin{array}{c}\text { G+ } \\
\mathbf{M}\end{array}$ & $\begin{array}{l}\text { H+ } \\
\text { G+ } \\
\text { M }\end{array}$ \\
\hline \multirow{6}{*}{$\begin{array}{c}256 \\
x \\
256\end{array}$} & \multirow{2}{*}{ Ayam } & LE & $\begin{array}{c}67 . \\
5\end{array}$ & 60 & $\begin{array}{c}67 . \\
5\end{array}$ & 60 & $\begin{array}{c}67 . \\
5\end{array}$ & 60 & 60 \\
\hline & & SR & 55 & $\begin{array}{c}52 . \\
5\end{array}$ & 60 & $\begin{array}{c}52 . \\
5\end{array}$ & 55 & $\begin{array}{c}52 . \\
5\end{array}$ & $\begin{array}{c}52 . \\
5\end{array}$ \\
\hline & \multirow{2}{*}{$\begin{array}{c}\text { Kam- } \\
\text { bing }\end{array}$} & LE & $\begin{array}{c}47 . \\
5\end{array}$ & $\begin{array}{c}42 . \\
5\end{array}$ & 45 & $\begin{array}{c}42 . \\
5\end{array}$ & $\begin{array}{c}47 . \\
5\end{array}$ & $\begin{array}{c}42 . \\
5\end{array}$ & $\begin{array}{c}42 . \\
5\end{array}$ \\
\hline & & SR & $\begin{array}{c}72 . \\
5 \\
\end{array}$ & $\begin{array}{c}62 . \\
5\end{array}$ & $\begin{array}{c}82 . \\
5\end{array}$ & $\begin{array}{c}62 . \\
5\end{array}$ & $\begin{array}{c}72 . \\
5\end{array}$ & $\begin{array}{c}62 . \\
5\end{array}$ & $\begin{array}{c}62 . \\
5\end{array}$ \\
\hline & \multirow{2}{*}{ Sapi } & LE & 75 & 45 & $\begin{array}{c}77 . \\
5\end{array}$ & 45 & 75 & 45 & 45 \\
\hline & & SR & $\begin{array}{c}67 . \\
5\end{array}$ & 65 & $\begin{array}{c}57 . \\
5\end{array}$ & 65 & $\begin{array}{c}67 . \\
5\end{array}$ & 65 & 65 \\
\hline \multicolumn{3}{|c|}{ Rata-rata } & $\begin{array}{l}64 . \\
17\end{array}$ & $\begin{array}{c}54 . \\
58\end{array}$ & 65 & $\begin{array}{l}54 . \\
58\end{array}$ & $\begin{array}{l}64 . \\
17\end{array}$ & $\begin{array}{l}54 . \\
58\end{array}$ & $\begin{array}{l}54 . \\
58\end{array}$ \\
\hline \multirow{6}{*}{$\begin{array}{c}512 \\
\mathrm{x} \\
512\end{array}$} & \multirow{2}{*}{ Ayam } & LE & $\begin{array}{c}52 . \\
5\end{array}$ & 55 & $\begin{array}{c}67 . \\
5\end{array}$ & 55 & $\begin{array}{c}52 . \\
5\end{array}$ & 55 & 55 \\
\hline & & SR & $\begin{array}{c}62 . \\
5 \\
\end{array}$ & 55 & 60 & $\begin{array}{c}52 . \\
5 \\
\end{array}$ & $\begin{array}{c}62 . \\
5 \\
\end{array}$ & 55 & $\begin{array}{c}52 . \\
5 \\
\end{array}$ \\
\hline & \multirow{2}{*}{$\begin{array}{l}\text { Kam- } \\
\text { bing }\end{array}$} & LE & 65 & 50 & 45 & 50 & 65 & 50 & 50 \\
\hline & & SR & 75 & $\begin{array}{c}47 . \\
5 \\
\end{array}$ & $\begin{array}{c}82 . \\
5\end{array}$ & $\begin{array}{c}47 . \\
5 \\
\end{array}$ & 75 & $\begin{array}{c}47 . \\
5 \\
\end{array}$ & $\begin{array}{c}47 . \\
5\end{array}$ \\
\hline & \multirow[t]{2}{*}{ Sapi } & LE & $\begin{array}{c}77 . \\
5\end{array}$ & 45 & 70 & 45 & $\begin{array}{c}77 . \\
5\end{array}$ & 45 & 45 \\
\hline & & SR & $\begin{array}{c}57 . \\
5\end{array}$ & $\begin{array}{c}62 . \\
5\end{array}$ & 55 & $\begin{array}{c}62 . \\
5\end{array}$ & $\begin{array}{c}57 . \\
5\end{array}$ & $\begin{array}{c}62 . \\
5 \\
\end{array}$ & $\begin{array}{c}62 . \\
5\end{array}$ \\
\hline \multicolumn{3}{|c|}{ Rata-rata } & 65 & $\begin{array}{l}52 . \\
50\end{array}$ & $\begin{array}{l}63 . \\
33 \\
\end{array}$ & $\begin{array}{l}52 . \\
08\end{array}$ & 65 & $\begin{array}{r}52 . \\
50 \\
\end{array}$ & $\begin{array}{r}52 . \\
08 \\
\end{array}$ \\
\hline
\end{tabular}

Keterangan: $\mathrm{LE}=$ Lemari es, $\mathrm{SR}=$ Suhu ruang, $\mathrm{H}=\mathrm{HSI}$ $\mathrm{G}=\mathrm{GLCM}, \mathrm{M}=$ Moment

TABEL VIII. PENGaRuh Resolusi TeRHADAP Hasil KLASIFIKASI JENIS+TINGKAT KESEGARAN DAGING

\begin{tabular}{|c|c|c|c|c|}
\hline & & \multicolumn{3}{|c|}{ Akurasi (\%) } \\
\cline { 3 - 5 } Reso- & Data & H+M (Jenis) & H+M (Jenis) & H+M (Jenis) \\
lusi & set & + & $\mathbf{+}$ & + \\
& & $\begin{array}{c}\mathbf{M} \\
\text { (Kesegaran) }\end{array}$ & $\begin{array}{c}\mathbf{H} \\
\text { (Kesegaran) }\end{array}$ & $\begin{array}{c}\text { H+M } \\
\text { (Kesegaran) }\end{array}$ \\
\hline $256 \mathrm{x}$ & LE & 46.67 & - & - \\
\cline { 3 - 5 } 256 & SR & 39.17 & - & - \\
\hline $512 \mathrm{x}$ & LE & - & 52.5 & 52.5 \\
\cline { 2 - 5 } 512 & SR & - & 39.17 & 39.17 \\
\hline
\end{tabular}

Keterangan: LE = Lemari es, SR = Suhu ruang, H = HSI, $\mathrm{M}=$ Moment

Berdasarkan hasil pengujian klasifikasi gabungan jenis dan tingkat kesegaran daging yang disajikan pada Tabel VIII, dapat dilihat bahwa akurasi yang diperoleh cukup rendah. Hal ini terjadi akibat penggabungan fitur jenis daging dan fitur tingkat kesegaran daging, dimana keduanya memiliki tingkat akurasi yang tidak terlalu tinggi. Hal lain yang mempengaruhi tingkat akurasi yang cukup rendah ini adalah untuk setiap data uji, harus terdapat 2 kesesuaian, yaitu kesesuaian jenis dan tingkat kesegaran daging.

Peningkatan resolusi citra membuat waktu komputasi untuk pelatihan dan pengujian menjadi semakin lama. Citra dengan resolusi 256x256 piksel membutuhkan waktu komputasi yang jauh lebih cepat jika dibandingkan dengan citra resolusi $512 \times 512$ piksel. Tabel IX menunjukkan waktu komputasi yang dibutuhkan untuk ekstraksi satu citra 256x256 piksel dan satu citra 512x512 piksel pada semua fitur.

TABEL IX. Pengaruh Resolusi Citra TerhadaP WAKTU KOMPUTASI DALAM SATUAN DETIK

\begin{tabular}{|c|c|c|c|c|c|c|c|}
\hline $\begin{array}{c}\text { Reso } \\
\text { lusi }\end{array}$ & $\mathbf{H}$ & $\mathbf{G}$ & $\mathbf{M}$ & $\mathbf{H}+\mathbf{G}$ & $\mathbf{H + M}$ & $\mathbf{G + M}$ & $\begin{array}{c}\mathbf{H + G} \\
+\mathbf{M}\end{array}$ \\
\hline 256 & 1.866 & 1.455 & 0.043 & 3.085 & 2.021 & 1.529 & 3.154 \\
\hline 512 & 6.922 & 3.532 & 0.214 & 9.182 & 7.279 & 2.424 & 9.254 \\
\hline
\end{tabular}

Keterangan: $\mathrm{H}=\mathrm{HSI}, \mathrm{G}=\mathrm{GLCM}, \mathrm{M}=$ Moment

Hasil pengujian pengaruh resolusi citra terhadap akurasi menunjukkan bahwa peningkatan resolusi tidak selalu berdampak baik pada hasil klasifikasi. Tingkat akurasi rata-rata dari masing-masing fitur mengalami penurunan dan peningkatan dari resolusi 256x256 ke 512x512. Selain itu dapat dilihat bahwa citra 256x256 piksel memiliki kecepatan yang jauh lebih baik dibandingkan citra $512 \times 512$ piksel dari sisi waktu komputasi. Oleh karena itu, citra dengan resolusi 256x256 piksel merupakan citra terbaik dilihat dari rata-rata akurasi dan waktu komputasi.

\section{B. Pengaruh rotasi terhadap akurasi}

Pengujian selanjutnya dilakukan untuk menguji pengaruh rotasi terhadap akurasi. Pengujian ini bertujuan untuk mengetahui pengaruh rotasi terhadap akurasi klasifikasi. Dataset yang digunakan yaitu citra dengan resolusi 256x256 piksel, dengan fitur yang diuji yaitu HSI, Moment, dan HSI+Moment. Rotasi dilakukan terhadap citra uji dengan arah rotasi $45^{\circ}, 90^{\circ}, 135^{\circ}$ dan $180^{\circ}$ searah dengan jarum jam (CW). Hasil dari pengujian pengaruh rotasi terhadap klasifikasi jenis daging, kesegaran daging ayam, kambing dan sapi dapat dilihat pada Tabel $\mathrm{X}$ dan Tabel XI.

TABEL X. Pengaruh Rotasi TerhadAP Hasil KLASIFIKASI JeNIS DAGING

\begin{tabular}{|c|c|c|c|c|}
\hline \multirow[b]{2}{*}{$\begin{array}{l}\text { Arah } \\
\text { rotasi }\end{array}$} & \multirow[b]{2}{*}{ Dataset } & \multicolumn{3}{|c|}{ Akurasi (\%) } \\
\hline & & HSI & Moment & $\begin{array}{c}\text { HSI+ } \\
\text { Moment }\end{array}$ \\
\hline \multirow{2}{*}{$0^{\circ}$} & LE & 80 & 68.33 & 78.33 \\
\hline & SR & 64.17 & 66.67 & 75 \\
\hline \multicolumn{2}{|c|}{ Rata-rata } & 72.09 & 67.50 & 76.67 \\
\hline \multirow{2}{*}{$\begin{array}{l}45^{\circ} \\
\mathrm{CW}\end{array}$} & LE & 22.5 & 66.67 & 58.3 \\
\hline & SR & 33.33 & 66.67 & 33.3 \\
\hline \multicolumn{2}{|c|}{ Rata-rata } & 27.92 & 66.67 & 45.80 \\
\hline \multirow{2}{*}{$\begin{array}{l}90^{\circ} \\
\mathrm{CW}\end{array}$} & LE & 80 & 68.33 & 78.33 \\
\hline & SR & 64.17 & 66.67 & 75 \\
\hline \multicolumn{2}{|c|}{ Rata-rata } & 72.09 & 67.50 & 76.67 \\
\hline \multirow{2}{*}{$\begin{array}{l}135^{\circ} \\
\mathrm{CW}\end{array}$} & LE & 22.5 & 66.67 & 58.3 \\
\hline & SR & 33.33 & 66.67 & 33.3 \\
\hline \multicolumn{2}{|c|}{ Rata-rata } & 27.92 & 66.67 & 45.80 \\
\hline \multirow{2}{*}{$\begin{array}{l}180^{\circ} \\
\mathrm{CW}\end{array}$} & LE & 80 & 68.33 & 78.33 \\
\hline & SR & 64.17 & 66.67 & 75 \\
\hline \multicolumn{2}{|c|}{ Rata-rata } & 72.09 & 67.50 & 76.67 \\
\hline
\end{tabular}


TABEL XI. PENGaruh Rotasi TERHADAP Hasil KLASIFIKASI TingKat Kesegaran Daging

\begin{tabular}{|c|c|c|c|c|c|}
\hline \multirow{2}{*}{$\begin{array}{l}\text { Arah } \\
\text { rotasi }\end{array}$} & \multirow{2}{*}{$\begin{array}{c}\text { Jenis } \\
\text { daging }\end{array}$} & \multirow{2}{*}{$\begin{array}{c}\text { Data } \\
\text { Set }\end{array}$} & \multicolumn{3}{|c|}{ Akurasi (\%) } \\
\hline & & & HSI & Moment & $\begin{array}{c}\text { HSI+ } \\
\text { Moment }\end{array}$ \\
\hline \multirow{6}{*}{$0^{\circ}$} & \multirow{2}{*}{ Ayam } & LE & 67.5 & 67.5 & 67.5 \\
\hline & & SR & 55 & 60 & 55 \\
\hline & \multirow{2}{*}{ Kambing } & LE & 47.5 & 45 & 47.5 \\
\hline & & SR & 72.5 & 82.5 & 72.5 \\
\hline & \multirow{2}{*}{ Sapi } & LE & 75 & 77.5 & 75 \\
\hline & & SR & 67.5 & 57.5 & 67.5 \\
\hline \multicolumn{3}{|c|}{ Rata-rata } & 64.17 & 65.00 & 64.17 \\
\hline \multirow{3}{*}{$\begin{array}{l}45^{\circ} \\
\mathrm{CW}\end{array}$} & \multirow{2}{*}{ Ayam } & LE & 0 & 42.5 & 0 \\
\hline & & SR & 2.5 & 45 & 2.5 \\
\hline & Kambing & LE & 0 & 62.5 & 0 \\
\hline \multirow{2}{*}{$\begin{array}{l}\text { Arah } \\
\text { rotasi }\end{array}$} & \multirow{2}{*}{$\begin{array}{c}\text { Jenis } \\
\text { daging }\end{array}$} & \multirow{2}{*}{$\begin{array}{c}\text { Data } \\
\text { Set }\end{array}$} & \multicolumn{3}{|c|}{ Akurasi (\%) } \\
\hline & & & HSI & Moment & $\begin{array}{c}\text { HSI+ } \\
\text { Moment }\end{array}$ \\
\hline \multirow{3}{*}{$\begin{array}{l}45^{\circ} \\
\mathrm{CW}\end{array}$} & Kambing & SR & 0 & 52.5 & 0 \\
\hline & \multirow{2}{*}{ Sapi } & LE & 0 & 35 & 0 \\
\hline & & SR & 2.5 & 60 & 2.5 \\
\hline \multicolumn{3}{|c|}{ Rata-rata } & 0.83 & 49.58 & 0.83 \\
\hline \multirow{6}{*}{$\begin{array}{l}90^{\circ} \\
\mathrm{CW}\end{array}$} & \multirow{2}{*}{ Ayam } & LE & 67.5 & 67.5 & 67.5 \\
\hline & & SR & 55 & 60 & 55 \\
\hline & \multirow{2}{*}{ Kambing } & LE & 47.5 & 45 & 47.5 \\
\hline & & SR & 72.5 & 82.5 & 72.5 \\
\hline & \multirow{2}{*}{ Sapi } & LE & 75 & 77.5 & 75 \\
\hline & & SR & 67.5 & 57.5 & 67.5 \\
\hline \multicolumn{3}{|c|}{ Rata-rata } & 64.17 & 65.00 & 64.17 \\
\hline \multirow{6}{*}{$\begin{array}{l}135^{\circ} \\
\mathrm{CW}\end{array}$} & \multirow{2}{*}{ Ayam } & LE & 0 & 42.5 & 0 \\
\hline & & SR & 2.5 & 45 & 2.5 \\
\hline & \multirow{2}{*}{ Kambing } & LE & 0 & 62.5 & 0 \\
\hline & & SR & 0 & 52.5 & 0 \\
\hline & \multirow{2}{*}{ Sapi } & LE & 0 & 35 & 0 \\
\hline & & SR & 2.5 & 60 & 2.5 \\
\hline & Rata-rata & & 0.83 & 49.58 & 0.83 \\
\hline & Avam & LE & 67.5 & 67.5 & 67.5 \\
\hline & & SR & 55 & 60 & 55 \\
\hline $180^{\circ}$ & Kambing & LE & 47.5 & 45 & 47.5 \\
\hline $\mathrm{CW}$ & Kambing & SR & 72.5 & 82.5 & 72.5 \\
\hline & Sani & LE & 75 & 77.5 & 75 \\
\hline & Dap1 & SR & 67.5 & 57.5 & 67.5 \\
\hline & Rata-rata & & 64.17 & 65.00 & 64.17 \\
\hline
\end{tabular}

Keterangan: LE = Lemari Es, SR = Suhu Ruang

Berdasarkan hasil pengujian pengaruh rotasi terhadap akurasi pada Tabel 10 dan Tabel 11, dapat disimpulkan bahwa melakukan rotasi $90^{\circ}$ dan $180^{\circ}$ searah jarum jam terhadap citra sama sekali tidak berpengaruh terhadap akurasi citra, baik dari akurasi per dataset maupun pada akurasi rata-rata akurasi. Pada fitur HSI hal ini disebabkan oleh pendekatan statistik, dimana nilai mean, median dan modus tidak akan berubah saat citra dirotasi. Sedangkan pada fitur Moment hal ini disebabkan oleh perhitungan dasar Moment pada Persamaan (12) yang menjumlahkan semua koordinat titik piksel dengan nilai elemen pada koordinat tersebut, sehingga tidak akan terdapat perubahan nilai fitur walaupun citra dirotasi.

Selanjutnya untuk rotasi $45^{\circ}$ dan $135^{\circ}$, terjadi penurunan tingkat akurasi yang sangat drastis, terutama pada fitur HSI. Hal ini dikarenakan oleh perubahan rotasi yang diberikan membuat citra memiliki orientasi diagonal, serta perubahan elemen dalam matriks citra itu sendiri. Sehingga nilai mean, median, modus dan variance dari citra yang dirotasi berbeda dengan citra asli.

Berdasarkan hasil pengujian pengaruh rotasi terhadap klasifikasi jenis daging dan tingkat kesegaran daging yang telah dilakukan, dipilih fitur terbaik dari masing-masing klasifikasi untuk digunakan dalam klasifikasi gabungan jenis dan tingkat kesegaran daging. Pada jenis daging digunakan fitur HSI+Moment untuk semua rotasi, sedangkan pada klasifikasi kesegaran digunakan fitur Moment untuk semua rotasi.

TABEL XII. PENGARUH Rotasi TERHADAP HASIL KLASIFIKASI JENIS+TINGKAT KESEGARAN DAGING

\begin{tabular}{|c|c|c|}
\hline \multirow[b]{2}{*}{ Rotasi } & \multirow[b]{2}{*}{ Dataset } & Akurasi (\%) \\
\hline & & $\begin{array}{c}\text { HSI+Moment (Jenis) } \\
+ \\
\text { Moment (Kesegaran) }\end{array}$ \\
\hline \multirow{2}{*}{$0^{\circ}$} & LE & 46.67 \\
\hline & SR & 39.17 \\
\hline \multirow{2}{*}{$\begin{array}{l}45^{\circ} \\
\mathrm{CW} \\
\end{array}$} & LE & 39.17 \\
\hline & SR & 16.67 \\
\hline \multirow{2}{*}{$\begin{array}{l}90^{\circ} \\
\mathrm{CW}\end{array}$} & LE & 46.67 \\
\hline & SR & 39.17 \\
\hline \multirow{2}{*}{$\begin{array}{l}135^{\circ} \\
\mathrm{CW}\end{array}$} & LE & 39.17 \\
\hline & SR & 16.67 \\
\hline \multirow{2}{*}{$\begin{array}{l}180^{\circ} \\
\mathrm{CW}\end{array}$} & LE & 46.67 \\
\hline & SR & 39.17 \\
\hline
\end{tabular}

Hasil pengujian klasifikasi gabungan jenis dan tingkat kesegaran daging untuk rotasi $0^{\circ}, 90^{\circ}$ dan $180^{\circ}$ yang disajikan pada Tabel XII memberikan hasil yang sama untuk setiap dataset. Hal ini menunjukkan bahwa perubahan pada rotasi $90^{\circ}$ dan $180^{\circ}$ untuk fitur HSI dan Moment sama sekali tidak memberikan pengaruh. Sedangkan untuk perubahan rotasi dari $0^{\circ}$ ke $45^{\circ}$ dan $135^{\circ}$ menunjukkan terjadinya penurunan tingkat akurasi keluaran, yaitu sebesar $7.5 \%$ pada dataset lemari es dan sebesar $22.5 \%$. Sehingga dapat disimpulkan bahwa perubahan rotasi hanya rotasi $45^{\circ}$ dan $135^{\circ}$ yang memberikan pengaruh pada tingkat akurasi pengujian.

\section{Analisis sebaran data fitur}

Sebaran data yang baik berarti terdapat perbedaan yang jelas antara fitur masing-masing kelas yang digunakan. Terdapat sebaran data dari beberapa fitur yang dianalisa yakni fitur HSI, fitur GLCM dan fitur invariant moment. Sebaran data fitur dapat dihasilkan dengan cara menghitung nilai fitur rata-rata dari semua data pelatihan. Pada analisis sebaran data ini, grafik sebaran data yang ditampilkan adalah sebaran data untuk fitur jenis daging dan kesegaran daging ayam, sedangkan sebaran data untuk fitur kesegaran daging kambing dan sapi terlampir.

\section{C.1. Analisis fitur HSI}

Terdapat 12 perhitungan statistik dalam fitur HSI mulai dari mean, median, modus serta variance dari masingmasing layer pada ruang warna HSI. 
1. Jenis daging

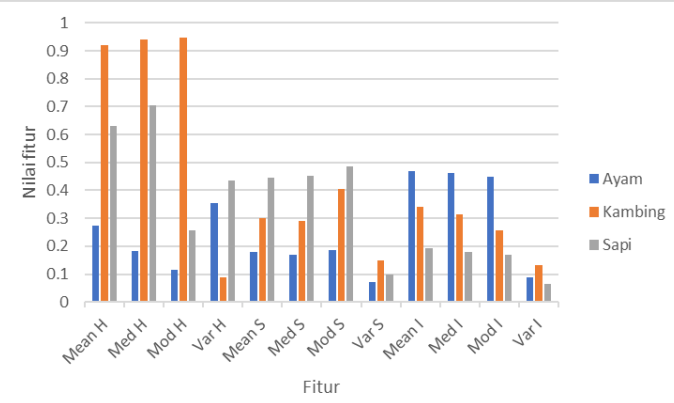

Gambar 5. Sebaran data fitur HSI dataset jenis daging lemari es

Grafik pada Gambar 5 menunjukkan bahwa sebaran data fitur HSI untuk dataset jenis daging lemari es cukup baik, terdapat perbedaan yang jelas antara data jenis daging ayam, kambing dan sapi di semua fitur. Hal inilah yang menyebabkan tingkat akurasi klasifikasi jenis daging lemari es yang cukup tinggi untuk fitur HSI.

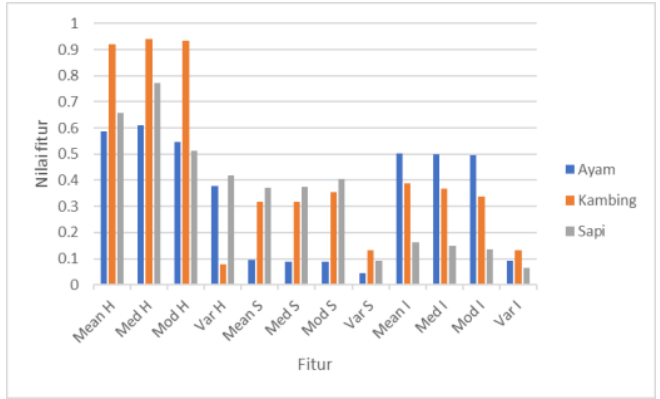

Gambar 6. Sebaran data fitur HSI dataset jenis daging suhu ruang

Grafik pada Gambar 6 menunjukkan bahwa sebaran data fitur HSI untuk dataset jenis daging suhu ruang cukup baik, namun tidak sebaik pada dataset lemari es. Karenanya, tingkat akurasi untuk dataset jenis daging suhu ruang lebih kecil dibandingkan jenis daging lemari es.

2. Kesegaran daging ayam

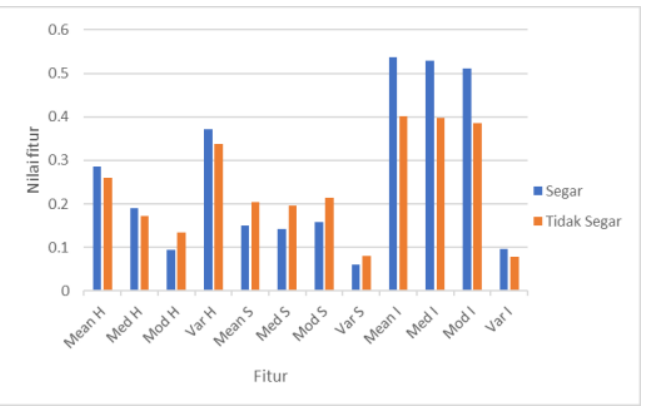

Gambar 7. Sebaran data fitur HSI dataset kesegaran daging ayam lemari

Sebaran data fitur HSI pada dataset kesegaran daging ayam lemari dapat dikatakan kurang baik, hal ini dikarenakan hanya terdapat perbedaan kecil antara kelas segar dengan kelas tidak segar. Oleh karena itu, tingkat akurasi klasifikasi untuk fitur ini tidak terlalu tinggi.

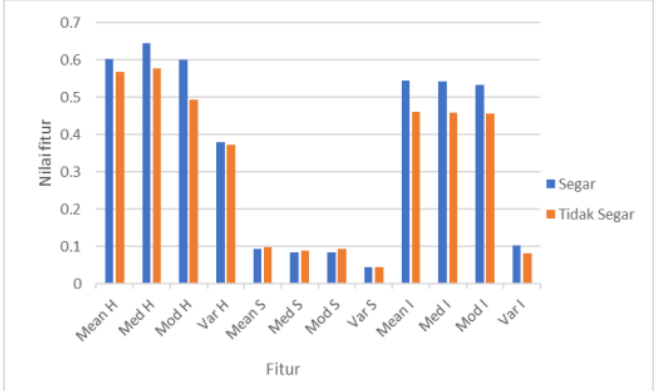

Gambar 8. Sebaran data fitur HSI dataset kesegaran daging ayam suhu ruang

Sama halnya dengan sebaran data fitur HSI pada dataset kesegaran daging ayam lemari es, sebaran data dataset suhu ruang ini juga kurang baik, tidak ada perbedaan besar antar kelas. Tingkat akurasi klasifikasi untuk fitur ini bahkan lebih rendah dari fitur dataset kesegaran ayam lemari es.

\section{C.2. Analisis fitur GLCM}

GLCM memiliki 20 fitur yang terdiri atas Contrast, Entropy, Energy (ASM), Correlation dan Homogeneity (IDM) yang dihitung pada masing-masing sudut $0^{\circ}, 45^{\circ}$, $90^{\circ}$ dan $135^{\circ}$. Pada penelitian ini, fitur GLCM memberikan hasil klasifikasi yang cukup buruk.

1. Jenis daging

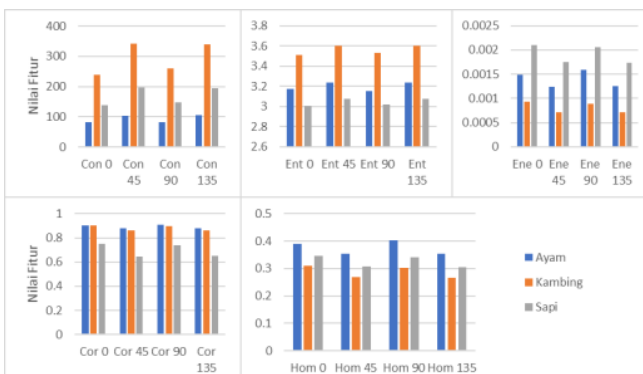

Gambar 9. Sebaran data fitur contrast, entropy, energy, correlation dan homogeneity dataset jenis daging lemari es

Berdasarkan grafik pada Gambar 9, fitur GLCM memiliki sebaran data yang cukup beragam untuk masingmasing fitur. Meskipun pada fitur contrast, entropy, dan energy terdapat perbedaan yang cukup jelas, namun akurasi yang dihasilkan sangat rendah. Hal yang sama juga terjadi pada sebaran data suhu ruang pada Gambar 10 , dengan akurasi yang lebih tinggi. 


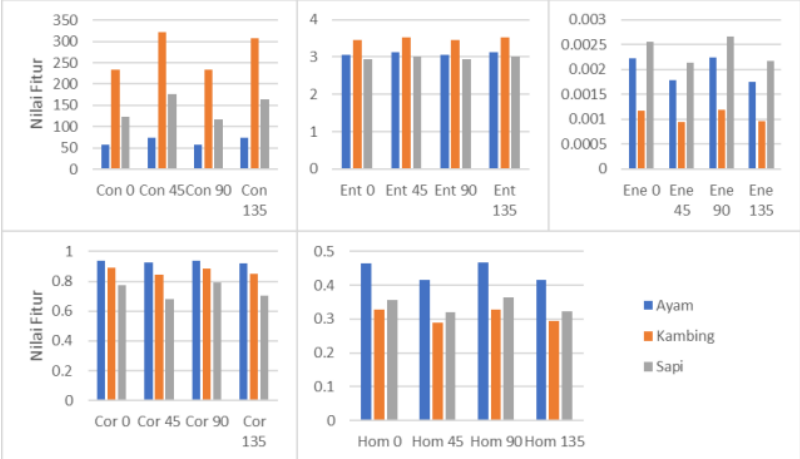

Gambar 10. Sebaran data fitur contrast, entropy, energy, correlation dan homogeneity dataset jenis daging suhu ruang

2. Kesegaran daging ayam

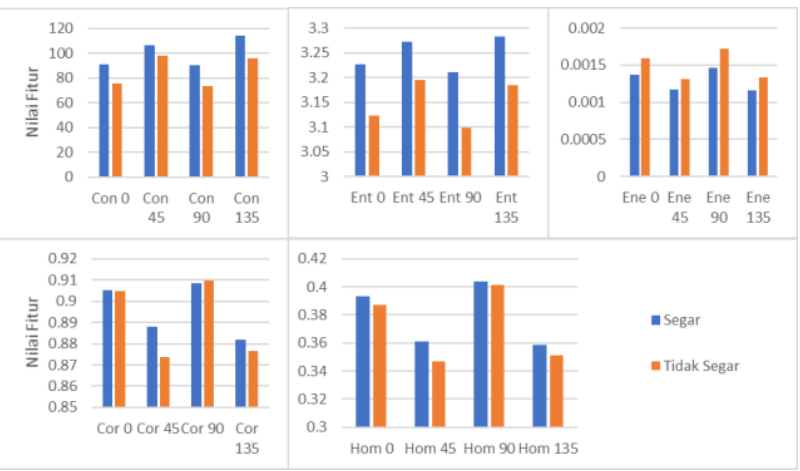

Gambar 11. Sebaran data fitur contrast, entropy, energy, correlation dan homogeneity dataset kesegaran daging ayam lemari es

Pada grafik sebaran data Gambar 11, dapat dilihat bahwa fitur contrast memiliki perbedaan antar kelas yang paling besar. Oleh karena itu tingkat akurasi yang diperoleh menggunakan fitur GLCM pada dataset ini cukup baik.

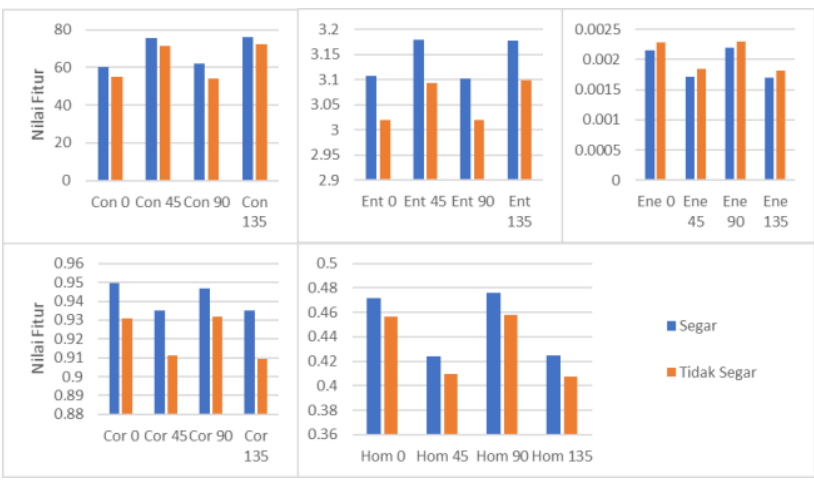

Gambar 12. Sebaran data fitur contrast, entropy, energy, correlation dan homogeneity dataset kesegaran daging ayam suhu ruang

Grafik sebaran data pada Gambar 12 menunjukkan kesamaan antara sebaran data dataset daging ayam lemari es dan suhu ruang, dimana fitur contrast memiliki perbedaan antar kelas yang paling besar. Namun, perbedaan tersebut tidak terlalu besar, sehingga akurasi yang diperoleh pada dataset suhu ruang ini lebih rendah daripada dataset daging ayam lemari es.

\section{C.3 Analisis fitur invariant moment}

Fitur Invariant Moment yang digunakan dalam penelitian ini terdiri atas 7 fitur moment. Nilai moment disimbolkan dengan $\phi(p h i)$ untuk fitur moment 1 sampai 7. Berikut merupakan grafik sebaran data pada fitur Invariant Moment untuk dataset jenis daging, kesegaran daging ayam, kambing dan sapi.

1. Jenis Daging

Grafik sebaran data fitur Moment untuk dataset jenis daging lemari es dan suhu ruang dapat dilihat pada Gambar 13 dan Gambar 14.

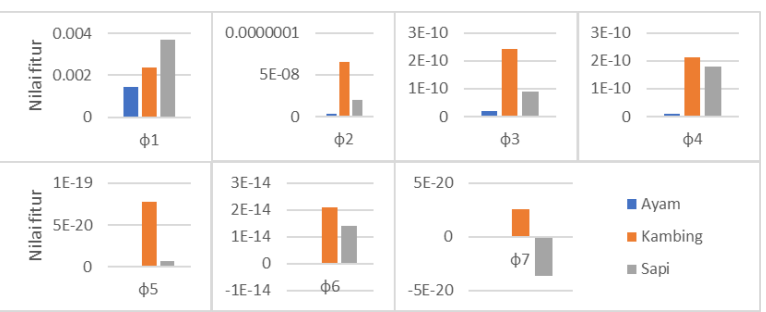

Gambar 13. Sebaran data fitur Moment dataset jenis daging lemari es

Seperti terlihat pada Gambar 13 bahwa sebaran data fitur Invariant Moment untuk dataset jenis daging lemari es dapat dikatakan cukup baik. Meski nilai beberapa fitur sangat kecil, terdapat perbedaan yang cukup jelas antara kelas daging ayam, kambing dan sapi. Dengan demikian nilai akurasi yang diperoleh menggunakan fitur ini mampu mencapai $68.33 \%$.

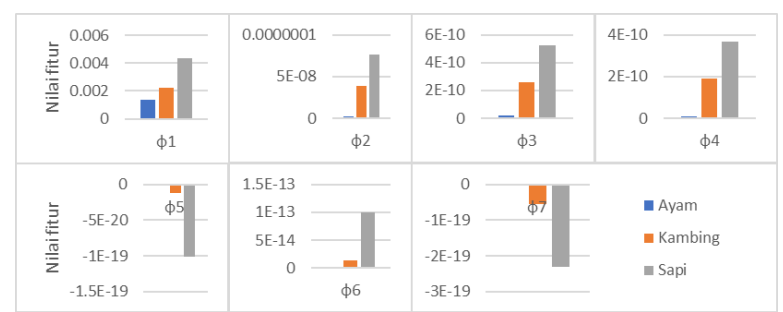

Gambar 14. Sebaran data fitur Moment dataset jenis daging suhu ruang

Seperti halnya sebaran data dataset lemari es, sebaran data dataset jenis daging suhu ruang juga cukup baik. Perbedaan antar kelas dapat terlihat jelas untuk semua fitur Moment.

2. Kesegaran daging ayam

Sebaran data fitur Moment dataset kesegaran daging ayam dapat dikatakan cukup baik, karena terdapat perbedaan antar kelas, meski tidak begitu besar. Dataset lemari es menghasilkan nilai akurasi yang lebih tinggi daripada dataset suhu ruang. Seperti yang bisa dilihat pada Gambar 15 untuk dataset lemari es dan Gambar 16 untuk dataset suhu ruang. 


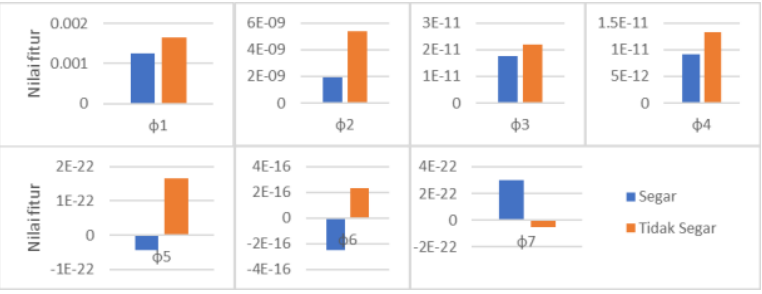

Gambar 15. Sebaran data fitur Moment dataset kesegaran daging ayam lemari es

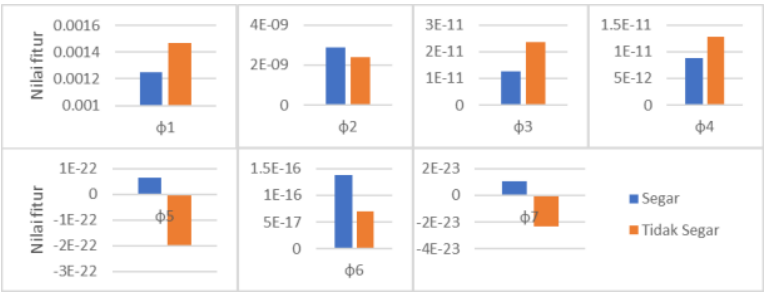

Gambar 16. Sebaran data fitur Moment dataset kesegaran daging ayam suhu ruang

\section{PENUTUP}

\section{A. Kesimpulan}

Berdasarkan hasil dari pengujian yang telah dilakukan, maka dapat disimpulkan bahwa:

1. Akurasi tertinggi untuk klasifikasi jenis daging yang diperoleh yaitu sebesar $90 \%$ menggunakan fitur kombinasi HSI dan Invariant Moment pada dataset citra lemari es dengan resolusi $512 \times 512$ piksel.

2. Tingkat akurasi keluaran tertinggi pada klasifikasi tingkat kesegaran daging sebesar $82.5 \%$ diperoleh menggunakan fitur Invariant Moment pada dataset citra daging kambing suhu ruang dengan resolusi 256x256 dan 512x512 piksel.

3. Resolusi citra $256 \times 256$ piksel merupakan resolusi terbaik jika dilihat dari rata-rata akurasi dan waktu komputasi.

4. Perubahan resolusi citra dari 256x256 ke 512x512 piksel tidak memberikan pengaruh signifikan pada akurasi yang diperoleh, dengan peningkatan akurasi rata-rata terbesar $2.93 \%$, akan tetapi peningkatan resolusi meningkatkan waktu komputasi.

5. Rotasi $90^{\circ}$ dan $180^{\circ}$ searah jarum jam tidak memberikan pengaruh sama sekali terhadap hasil klasifikasi menggunakan fitur HSI dan Moment, sedangkan penggunaan rotasi $45^{\circ}$ dan $135^{\circ}$ menyebabkan penurunan tingkat akurasi.

6. Sistem klasifikasi jenis dan tingkat kesegaran daging menggunakan metode klasifikasi LDA telah berhasil dibangun, akan tetapi tingkat akurasi yang diperoleh cukup rendah, dengan akurasi sebesar $39.17 \%$ untuk klasifikasi gabungan jenis dan tingkat kesegaran daging pada suhu ruang.

\section{B. Saran}

Adapun saran untuk penelitian lebih lanjut, yaitu:

1. Lakukan klasifikasi jenis dan tingkat kesegaran daging menggunakan metode klasifikasi yang berbeda dengan metode LDA.
2. Lakukan seleksi fitur untuk mengeliminasi fitur yang tidak memberikan pengaruh positif terhadap hasil klasifikasi.

3. Pastikan pencahayaan selalu konsisten pada saat pengambilan data citra.

4. Perbanyak jumlah jenis daging yang diklasifikasikan.

\section{DAFTAR PUSTAKA}

[1] K. P. RI, "Statistik Peternakan dan Kesehatan Hewan," Direktorat Jendral Peternakan dan Kesehatan Hewan, 2017.

[2] S. M. Suwito, B. Hidayat, and Dea, "Klasifikasi Jenis Dan Kualitas Daging Konsumsi Berdasarkan Analisis Tekstur Dan Warna Dengan Metode Transformasi Curvelet Dan KNearest Neighbor, ” Bandung: Universitas Telkom, 2012.

[3] R. Farinda, Z. R. Firmansyah, C. Sulton, I. G. P. S. Wijaya, and F. Bimantoro, "Beef Quality Classification based on Texture and Color Features using SVM Classifier," $J$. Telemat. Informatics, vol. 6, no. 3, 2018.

[4] A. Septiarini, "Pengenalan Pola Pada Citra Digital Dengan Fitur Momen Invariant," Inform. Mulawarman J. Ilm. Ilmu Komput., vol. 7, no. 1, pp. 8-11, 2012.

[5] N. Lihayati, R. E. Pawening, M. Furqan, J. T. Informatika, and G. L. C. Matrix, "Klasifikasi Jenis Daging Berdasarkan Tekstur Menggunakan Metode Gray Level Coocurent Matrix," Pros. SENTIA, vol. 8, pp. 305-310, 2016.

[6] Neneng and Y. Fernando, "Klasifikasi Jenis Daging Berdasarkan Analisis Citra Tekstur Gray Level CoOccurrence Matrices (GLCM) Dan Warna," Semin. Nas. Sains dan Teknol. 2017, pp. 1-2, 2017.

[7] E. Budianita, J. Jasril, and L. Handayani, "Implementasi Pengolahan Citra dan Klasifikasi K-Nearest Neighbour Untuk Membangun Aplikasi Pembeda Daging Sapi dan Babi," J. Sains dan Teknol. Ind., vol. 12, no. 2, pp. 242-247, 2015.

[8] I. G. R. A. Sugiartha, M. Sudarma, and I. M. O. Widyantara, "Ekstraksi Fitur Warna, Tekstur dan Bentuk untuk Clustered-Based Retrieval of Images (CLUE)," Maj. Ilm. Teknol. Elektro, vol. 16, no. 1, p. 85, 2017.

[9] K. Xiao, G. Gao, and L. Shou, "An Improved Method for Detecting Pork Freshness Based on Computer Vision in Online System," Sensors and Transducers, vol. 169, no. 4, pp. 42-48, 2014.

[10] G. K. Lim Resmana, Raymond, "Face Recognition Menggunakan Metode Linear Discriminant Analysis (LDA)," Kommit, p. 9, 2002.

[11] Fandiansyah, J. Y. Sari, and I. P. Ningrum, "Pengenalan Wajah Menggunakan Metode Linear Discriminant Analysis dan k Nearest Neighbor," J. Ultim., vol. 9, no. 1, pp. 1-9, 2018.

[12] I. G. P. S. Wijaya, A. A. Firdaus, A. P. J. Dwitama, and Mustiari, "Pengenalan Ekspresi Wajah Menggunakan DCT Dan LDA Untuk Aplikasi Pemutar Musik (MOODSIC)," J. Teknol. Inf. dan Ilmu Komput., vol. 5, no. 5, pp. 559-566, 2018.

[13] A. H. T. Prihharsanti, "Populasi Bakteri dan Jamur pada Daging Sapi dengan Penyimpanan Suhu Rendah," Sains Peternak., vol. 7, no. 2, p. 66, 2016.

[14] P. E. Sari, "Pengaruh Lama Perendaman Dengan Menggunakan Larutan Daun Salam (Syzygium Polyanthum) Sebagai Pengawet Terhadap Komposisi Kimia Dan Awal Kebusukan Daging Broiler," Universitas Lampung, 2018.

[15] E. R. Swedia and M. Cahyanti, "Algoritma Tranformasi 
Ruang Warna, ” Depok: Universitas Gunadarma, 2010.

[16] R. M. Haralick, K. Shanmugam, and I. Dinstein, "Textural
Features for Image Classification," IEEE Trans. Syst. Man Cybern., pp. 610-621, 1973. 